\title{
Effects of activin A and follistatin on developmental kinetics of bovine embryos: cinematographic analysis in a chemically defined medium
}

\author{
K. Yoshioka, C. Suzuki and S. Iwamura \\ Laboratory of Theriogenology, National Institute of Animal Health, Tsukuba 305-0856, Japan
}

\begin{abstract}
The effects of recombinant human activin A and follistatin on the developmental kinetics of bovine presumptive zygotes matured and fertilized in vitro using time-lapse cinematography were investigated. The presumptive zygotes were cultured for 9 days in a chemically defined medium (modified synthetic oviduct fluid, control) and modified synthetic oviduct fluid supplemented with activin A or follistatin. Development under cine-recording conditions was similar to that in an incubator. Addition of activin A to modified synthetic oviduct fluid increased, while addition of follistatin decreased, the percentage of zygotes that developed to morulae and blastocysts. Follistatin significantly prolonged the timing of development to the 9-16cell stage compared with the control and activin A media. Activin A significantly shortened the duration of the third cell cycle compared with the control, but follistatin significantly prolonged the fourth cell cycle compared with the control and activin A. Developmental arrest ('lag-phase') during the 4-8-cell stage was observed in 95\% of embryos developed to more than the 9-16-cell stage in all treatments. The greater the number of cells at the onset of the lag-phase, the earlier the onset of the phase and the shorter the duration of the phase, the further embryos were able to develop by day 9 in all treatments. The number of cells at the onset of the lag-phase in the medium containing activin A was significantly higher than it was in control or follistatincontaining media. Moreover, activin A significantly shortened the duration of the lagphase compared with follistatin. The present results indicate that activin A may enhance in vitro development of bovine embryos by improving developmental kinetics, especially by increasing the number of cells at the onset of the lag-phase and shortening the duration of this phase.
\end{abstract}

\section{Introduction}

The addition of activin A to the culture medium increases the developmental rate of bovine embryos produced in vitro to the blastocyst stage, and follistatin antagonizes the action of activin A on the development of embryos (Yoshioka and Kamomae, 1996; Yoshioka et al., 1998a). Bovine preimplantation embryos continuously express mRNAs encoding activin receptors from the one-cell to the hatched blastocyst stage (Yoshioka et al., 1998b). These results indicate that activin A plays a functional role in the development of bovine embryos. However, activin A or follistatin have no effect on the cell proliferation of bovine preimplantation embryos, that is, no increase in cell number is noted in blastocysts (Yoshioka et al., 1998a). Thus, the exact role of activin $\mathrm{A}$ in the development of bovine embryos remains to be determined.

In vitro development of bovine embryos produced by in vitro maturation/in vitro fertilization (IVM/IVF) is generally

Received 10 May 1999 slower than in vivo development, especially after the eightcell stage has been reached (Barnes and Eyestone, 1990). In particular, there is a significant developmental arrest or 'lagphase' in cultured bovine embryos between the four- and the eight-cell stages (Grisart et al., 1994; Van Langendonckt et al., 1997). In cattle, the major zygotic gene activation occurs during this arrest period (Frei et al., 1989; Barnes and First, 1991).

Cinematography is a suitable tool for the analysis of the developmental kinetics of individual embryos and has proved useful in investigating the behaviour of mouse (Mulnard, 1967), hamster and rhesus monkey (Bavister, 1988) and bovine embryos (Massip and Mulnard, 1980; Grisart et al., 1994; Van Langendonckt et al., 1997; Holm et al., 1998). Time-lapse cinematography facilitates detailed study of the developmental kinetics of embryos, without compromising embryo viability (Grisart et al., 1994). Accurate timing of development of individual embryos should provide useful information on preimplantation features, such as cell cycle duration, embryo compaction, 
blastulation and hatching and the lengthening of the cell cycle at the time when genomic expression resumes under various culture conditions.

The development-enhancing effects of activin A and the development-impeding effects of follistatin were observed in bovine embryos until the fourth cell cycle (Yoshioka et al., 1998a). These cytokines may affect the developmental kinetics of embryos, especially during this period. Therefore, the present study investigated the effects of activin A and follistatin on the developmental kinetics of bovine embryos produced in vitro by time-lapse cinematography. Cell cycle duration, the lag-phase, the formation of the morula and blastocyst, and hatching were recorded and calculated to determine the accurate timing of each phase of embryonic development.

\section{Materials and Methods}

\section{In vitro maturation and in vitro fertilization of oocytes}

Oocytes were collected from the ovaries of slaughtered cows and were matured and fertilized in vitro using the method described by Yoshioka and Kamomae (1996). Briefly, intact cumulus-oocyte complexes were allowed to mature for $22 \mathrm{~h}$ in $25 \mathrm{mmol}$ Hepes-buffered TCM199 $\mathrm{l}^{-1}$ (Sigma Chemical Co., St. Louis, MO) supplemented with 10\% (v/v) heat-inactivated fetal calf serum (Gibco Life Technologies, Grand Island, NY), 0.2 mmol sodium pyruvate $\mathrm{l}^{-1}, 0.02$ iu pig FSH ml ${ }^{-1}$ (Sigma), $1 \mu \mathrm{g}$ oestradiol $\mathrm{ml}^{-1}$ (Sigma) and $50 \mu \mathrm{g}$ gentamicin sulphate $\mathrm{ml}^{-1}$ at $39^{\circ} \mathrm{C}$ in humidified air with $5 \%$ $\mathrm{CO}_{2}$. Mature cumulus-oocyte complexes were incubated for fertilization in BO medium supplemented with $2.5 \mathrm{mmol}$ theophylline $\mathrm{ml}^{-1}, 5 \mu \mathrm{g}$ heparin $\mathrm{ml}^{-1}$ (Sigma), $50 \mu \mathrm{g}$ gentamicin sulphate $\mathrm{ml}^{-1}$ and $3 \mathrm{mg}$ fatty acid-free BSA ml $\mathrm{l}^{-1}$ (Sigma) with $5 \times 10^{6}$ Percoll-separated spermatozoa $\left(\right.$ Percoll $^{\circledR}$, Amersham Pharmacia Biotech, Uppsala) $\mathrm{ml}^{-1}$ for $20 \mathrm{~h}$ at $39^{\circ} \mathrm{C}$ in a humidified atmosphere containing $5 \% \mathrm{CO}_{2}: 5 \% \mathrm{O}_{2}: 90 \% \mathrm{~N}_{2}$.

\section{Culture of embryos}

After $20 \mathrm{~h}$ of co-incubation with spermatozoa, presumptive zygotes were stripped of cumulus cells by vortexing for $4 \mathrm{~min}$ in glucose-free TALP-Hepes (Bavister et al., 1983). Denuded zygotes were each washed twice in TALP-Hepes and culture medium. The basal culture medium was modified synthetic oviduct fluid (mSOF) medium (Takahashi and First, 1992) with some modifications. mSOF consisted of $107.7 \mathrm{mmol} \mathrm{NaCl}^{-1}, 7.16$ $\mathrm{mmol} \mathrm{KCl}{ }^{-1}, 1.71 \mathrm{mmol} \mathrm{CaCl}_{2} \mathrm{l}^{-1}, 0.49 \mathrm{mmol} \mathrm{mgCl}_{2} \mathrm{l}^{-1}, 0.35$ mmol KH $\mathrm{PO}_{4} \mathrm{l}^{-1}, 25.07 \mathrm{mmol} \mathrm{NaHCO} \mathrm{l}^{-1}, 3.3 \mathrm{mmol}$ sodium lactate $1^{-1}, 0.3 \mathrm{mmol}$ sodium pyruvate $\mathrm{l}^{-1}, 1.0 \mathrm{mmol}$ glucose $\mathrm{l}^{-1}, 1.0 \mathrm{mmol}$ glutamine $\mathrm{1}^{-1}, 2 \%(\mathrm{v} / \mathrm{v})$ essential amino acids mixture (Sigma), 1\% (v/v) non-essential amino acids mixture (Sigma), $50 \mu \mathrm{g}$ gentamicin sulphate $\mathrm{ml}^{-1}$ and $3 \mathrm{mg}$ polyvinyl alcohol ml-1 (Sigma). Denuded zygotes were cultured in 40 $\mu \mathrm{l}$ droplets of $\mathrm{mSOF}$ (for control), mSOF containing $10 \mathrm{ng}$ recombinant human activin $\mathrm{A} \mathrm{ml}^{-1}$ (Austral Biologicals, San Roman, CA) or $10 \mathrm{ng}$ recombinant human follistatin $\mathrm{ml}^{-1}$
(rhFS-288, lot number B3904, NHPP, NIDDK (Rockville, MD), NICHD, USDA) covered with mineral oil (Nacalai Tesque, Kyoto, Japan) at $39^{\circ} \mathrm{C}$ in a humidified atmosphere of $5 \% \mathrm{CO}_{2}: 5 \% \mathrm{O}_{2}: 90 \% \mathrm{~N}_{2}$. Each droplet contained 25 zygotes. The culture was run for 9 days without changing the medium during this period.

\section{Time-lapse cinematography}

A plexiglas thermoregulated box (Sankei, Tokyo) was adapted to fit onto an inverted microscope (TMD 300, Nikon Diaphot, Tokyo). A cinematographic chamber (Sankei) with an internal temperature maintained at $39^{\circ} \mathrm{C}$ was placed on the microscope plate. Embryos were cultured in a $35 \mathrm{~mm}$ plastic Petri dish (Falcon 1008, Becton Dickinson, Franklin Lakes, NJ) placed directly inside the closed cinematographic chamber. A $5 \% \quad \mathrm{CO}_{2}: 5 \% \quad \mathrm{O}_{2}: 90 \% \quad \mathrm{~N}_{2}$ gas mixture was humidified and warmed by passing through sterile water at $39^{\circ} \mathrm{C}$ in a gas bubbler bottle and flushed into the chamber at a constant flow rate of $25 \mathrm{ml} \mathrm{min}^{-1}$ throughout the culture period.

The cine-recording equipment consisted of a colour video camera (KY-F55, Sankei) connected to a time-lapse component recording video system (LVR-3000AN-NS, Sony, Tokyo). A single frame was recorded every minute. The microscope light was switched on a few seconds before and switched off immediately after the frame was recorded each time. The experiment was carried out in a dark room.

\section{Experimental protocol}

The development of embryos from the one-cell stage to the hatched blastocyst stage was recorded continuously throughout the 9 day culture by time-lapse cinematography. The developmental kinetics were investigated under three culture treatments: control (mSOF alone), ACT (mSOF supplemented with activin A) and FS (mSOF supplemented with follistatin). Four movies were recorded for each treatment condition. In addition, another batch of embryos was cultured simultaneously in an incubator (APMW-36, Astec, Shime) at $39^{\circ} \mathrm{C}$ in a humidified atmosphere containing $5 \% \mathrm{CO}_{2}: 5 \% \mathrm{O}_{2}: 90 \% \mathrm{~N}_{2}$ under the three treatment conditions, control, ACT and FS. The recorded movies were analysed at a later stage by detecting, for each embryo, the time of appearance of every cleavage from the two- to the nine-cell stage, cleavage to the 16-cell stage, the formation of the morula and blastocyst, and hatching using $\times 240$ total magnification. At $48 \mathrm{~h}$ after insemination, the rates of cleavage and of formation of five- to eight-cell embryos were recorded for both groups of incubator and time-lapse culture systems. The rates of formation of morulae at $120 \mathrm{~h}$ after insemination, blastocysts at $192 \mathrm{~h}$ after insemination and hatching at $216 \mathrm{~h}$ after insemination were also recorded for both groups.

\section{Statistical analysis}

The differences in mean percentages of cleavage and in the formation of five- to eight-cell embryos at $48 \mathrm{~h}$ after 
insemination, morulae at $120 \mathrm{~h}$ after insemination, blastocysts at $192 \mathrm{~h}$ after insemination and hatching at $216 \mathrm{~h}$ after insemination were analysed by two-way (culture media and systems) analysis of variance (ANOVA). One-way ANOVA was used to compare the mean times of the first appearance of early cleavage, morula, blastocyst and hatching blastocyst stages recorded on the movies. The mean time when these developmental stages occurred most often (time of peak emergence), the number of embryos at the time of peak emergence and the cell cycle duration were also calculated and subjected to one-way ANOVA. Developmental arrest ('lag-phase') was considered to have occurred when the interval between two mitoses during the four- to eight-cell stages was at least two times the duration of the second cell cycle (Grisart et al., 1994). The number of cells and time at which the the lag-phase began, the duration of the lag-phase, and the developmental stage reached by day 9 were calculated for each embryo. Lag-phase data were subjected to two-way (culture treatments and stage reached at day 9) ANOVA. When ANOVA showed a significant effect for treatment, treatments were compared by Fisher's PLSD test. The relationship between the lag-phase and the developmental stage reached at day 9 was examined using Spearman's rank correlation. $P<0.05$ denoted the presence of a statistically significant difference.

\section{Results}

Validity of the time-lapse analysis methods, and effects of activin $A$ and follistatin on developmental rate

A total of 600 presumptive zygotes was cultured, including 300 each in the incubator and time-lapse culture systems. The number of embryos reaching the two- to fourcell and five- to eight-cell stages at $48 \mathrm{~h}$ after insemination, morula stage at $120 \mathrm{~h}$ after insemination, blastocyst stage at $192 \mathrm{~h}$ after insemination and hatched blastocyst stage at 216 $h$ after insemination were not significantly different between the two culture systems at any developmental stage. On the basis of this finding, the overall percentages of embryos at each developmental stage were calculated for both culture systems (Table 1).

There were no significant differences in the percentage of embryos cleaved and developed to the five- to eight-cell stage after $48 \mathrm{~h}$ in vitro fertilization among the culture systems and treatment studied (Table 1). Treatment of cultures with activin A significantly increased the number and proportion of morulae at $120 \mathrm{~h}$ after insemination and the number and proportion of blastocysts at $192 \mathrm{~h}$ after insemination, compared with control $(P<0.05)$ and FS cultures $(P<0.001)$. Activin A also increased the proportion of hatched blastocysts at $216 \mathrm{~h}$ after insemination, compared with control and FS treatments $(P<0.01)$. However, FS significantly reduced the percentages of morulae at $120 \mathrm{~h}$ after insemination and blastocysts at $192 \mathrm{~h}$ after insemination, compared with controls $(P<0.05)$.

\section{Kinetics of development: distribution of cleavage divisions}

The distribution pattern of embryos at each developmental stage during the culture period is shown (Fig. 1). The distribution curves for the two-cell (Fig. 1a) and three- to four-cell (Fig. 1b) stages were characterized by a sharp increase to a peak value followed by a sharp decrease of the percentage of embryos, irrespective of treatment. The curves for the five- to eight-cell stage (Fig. 1c) were characterized by a rapid increase to peak value at about $54 \mathrm{~h}$ after insemination, reaching a plateau lasting approximately $30 \mathrm{~h}$, followed by a slow decrease. After the 9-16-cell stage (Fig. 1d-f), the increase and decrease in the percentage of embryos occurred more slowly.

The time of first appearance at a given stage, the time of peak emergence and the number of embryos at the time of peak emergence are summarized (Tables 2 and 3). Culture with follistatin significantly $(P<0.001)$ prolonged the mean time to first appearance of 9-16-cell embryos compared with control and ACT cultures (Table 2). There was no significant difference in the time of peak emergence at any stage among

Table 1. Effect of activin A and follistatin on development of bovine embryos cultured in incubators or under time-lapse cinematography

\begin{tabular}{|c|c|c|c|c|c|c|c|}
\hline \multirow[b]{2}{*}{ Medium } & \multirow[b]{2}{*}{$\begin{array}{l}\text { Culture } \\
\text { system }\end{array}$} & \multirow[b]{2}{*}{$\begin{array}{c}\text { Number of presumptive } \\
\text { zygotes cultured }\end{array}$} & \multicolumn{5}{|c|}{ Number $(\%)$ of embryos developed to } \\
\hline & & & $\begin{aligned} \geq & \text { Two-cell } \\
& (48 \mathrm{~h})^{*}\end{aligned}$ & $\begin{array}{l}\text { Five- to eight-cell } \\
\qquad(48 \mathrm{~h})\end{array}$ & $\begin{array}{c}\text { Morula } \\
(120 \mathrm{~h})\end{array}$ & $\begin{array}{l}\text { Blastocyst } \\
\text { (192 h) }\end{array}$ & $\begin{array}{l}\text { Hatched blastocyst } \\
(216 \mathrm{~h})\end{array}$ \\
\hline \multirow[t]{3}{*}{ Control } & Incubator & 100 & $82(82.0)$ & $47(47.0)$ & $34(34.0)^{\mathrm{ab}}$ & $27(27.0)^{\mathrm{a}}$ & $6(6.0)^{a}$ \\
\hline & Time-lapse & 100 & $81(81.0)$ & $56(56.0)$ & $32(32.0)^{\mathrm{a}}$ & $28(28.0)^{\mathrm{a}}$ & $5(5.0)^{\mathrm{a}}$ \\
\hline & Overall & 200 & $166(83.0)$ & $103(51.5)$ & $66(33.0)^{\mathrm{a}}$ & $55(27.5)^{\mathrm{a}}$ & $11(5.5)^{\mathrm{a}}$ \\
\hline \multirow[t]{3}{*}{ Activin A } & Incubator & 100 & $82(82.0)$ & $52(52.0)$ & $46(46.0)^{a}$ & $42(42.0)^{b}$ & $16(16.0)^{b}$ \\
\hline & Time-lapse & 100 & $87(87.0)$ & $57(57.0)$ & $40(40.0)^{\mathrm{a}}$ & $42(42.0)^{b}$ & $14(14.0)^{\mathrm{b}}$ \\
\hline & Overall & 200 & $169(84.5)$ & $109(54.5)$ & $86(43.0)^{b}$ & $84(42.0)^{\mathrm{b}}$ & $30(15.0)^{b}$ \\
\hline \multirow[t]{3}{*}{ Follistatin } & Incubator & 100 & $86(86.0)$ & $44(44.0)$ & $25(25.0)^{b}$ & $21(21.0)^{\mathrm{a}}$ & $7(7.0)^{\mathrm{a}}$ \\
\hline & Time-lapse & 100 & $84(84.0)$ & $50(50.0)$ & $17(17.0)^{\mathrm{b}}$ & $16(16.0)^{\mathrm{c}}$ & $4(4.0)^{\mathrm{a}}$ \\
\hline & Overall & 200 & $170(85.0)$ & $94(47.0)$ & $42(21.0)^{c}$ & $37(18.5)^{\mathrm{c}}$ & $11(5.5)^{\mathrm{a}}$ \\
\hline
\end{tabular}

Data are pooled from four replicates.

*Time after in vitro insemination.

${ }^{\mathrm{abc}}$ Values in the same column of the same culture system with different superscripts are significantly $\operatorname{different}\left({ }^{\mathrm{ab}} P<0.05\right.$; ${ }^{\mathrm{ac}} P<0.05$; $\left.{ }^{\mathrm{bc}} P<0.001\right)$. 
Table 2. Effect of activin A and follistatin on the time of first appearance of early cleavage stages in bovine embryos

\begin{tabular}{|c|c|c|c|}
\hline \multirow[b]{2}{*}{ Stage } & \multicolumn{3}{|c|}{ Time of first appearance $(n)$} \\
\hline & Control & Activin A & Follistatin \\
\hline Two-cell & 31 h $02 \pm 1$ h 15 (83) & 30 h $19 \pm 0$ h $23(87)$ & 29 h $32 \pm 0$ h 19 (84) \\
\hline Three- to four-cell & 38 h $26 \pm 1$ h $08(80)$ & 38 h $14 \pm 0$ h 38 (82) & 39 h $52 \pm 1$ h 55 (79) \\
\hline Five- to eight-cell & 49 h $01 \pm 2$ h 01 (70) & 47 h $24 \pm 1$ h 21 (77) & 48 h $17 \pm 1$ h $23(68)$ \\
\hline 9-16-cell & 92 h $34 \pm 1$ h $56^{a}(63)$ & 89 h $23 \pm 1$ h $51^{\text {a }}(68)$ & 100 h $49 \pm 2$ h $07^{\mathrm{b}}(58)$ \\
\hline Morula & 117 h $44 \pm 1$ h 35 (45) & 116 h $59 \pm 1$ h 33 (61) & 121 h $41 \pm 2$ h $13(37)$ \\
\hline Blastocyst & 173 h $00 \pm 2$ h 58 (30) & 170 h $54 \pm 2$ h 25 (47) & 175 h $05 \pm 3$ h 39 (21) \\
\hline Hatched blastocyst & 195 h $26 \pm 7$ h 17 (5) & 195 h $11 \pm 4$ h $42(14)$ & 200 h $28 \pm 6$ h $54(4)$ \\
\hline
\end{tabular}

Data are pooled from four replicates.

*Mean \pm SEM values expressed in $h$ and min after in vitro insemination.

${ }^{\mathrm{ab}}$ Values in the same row with different superscripts are significantly different $\left({ }^{\mathrm{ab}} P<0.001\right)$.

Table 3. Effect of activin A and follistatin on time of peak emergence and numbers at time of peak emergence of early embryonic stages in bovine embryos

\begin{tabular}{|c|c|c|c|c|c|c|}
\hline \multirow[b]{3}{*}{ Stage } & \multicolumn{6}{|c|}{ Peak emergence } \\
\hline & \multicolumn{3}{|c|}{ Time $^{*}$} & \multicolumn{3}{|c|}{ Percentage of embryos ${ }^{+}$} \\
\hline & Control & Activin A & Follistatin & Control & Activin A & Follistatin \\
\hline Two-cell & 31 h $31 \pm 0$ h 50 & 32 h $51 \pm 0$ h 38 & $32 \mathrm{~h} 03 \pm 0$ h 46 & 65 & 67 & 73 \\
\hline Three- to four-cell & 39 h $29 \pm 1$ h 02 & 39 h $27 \pm 0$ h 35 & 39 h $51 \pm 0$ h 36 & 58 & 60 & 67 \\
\hline Five- to eight-cell & 64 h $21 \pm 7$ h 58 & 55 h $20 \pm 6$ h 02 & 61 h $39 \pm 6$ h 46 & 62 & 70 & 66 \\
\hline 9-16-cell & 102 h $38 \pm 3$ h 13 & 104 h $18 \pm 1$ h 44 & 105 h $30 \pm 6$ h 29 & 52 & 56 & 45 \\
\hline Morula & 133 h $20 \pm 3$ h 00 & 141 h $44 \pm 2$ h 03 & 147 h $05 \pm 7$ h 04 & $44^{\mathrm{ab}}$ & $60^{\mathrm{a}}$ & $37^{\mathrm{b}}$ \\
\hline Blastocyst & 188 h $40 \pm 2$ h 22 & 189 h $49 \pm 5$ h 00 & 192 h $35 \pm 7$ h 11 & $29^{\mathrm{ab}}$ & $41^{\mathrm{a}}$ & $18^{\mathrm{b}}$ \\
\hline
\end{tabular}

Data are pooled from four replicates.

*Mean \pm SEM values expressed in $\mathrm{h}$ and $\min$ after in vitro insemination.

'Percentages of presumptive zygotes.

${ }^{a b}$ Values in the same row with different superscripts are significantly different $\left({ }^{a b} P<0.05\right)$.

Table 4. Number of cells in bovine embryos cultured in media containing activin A and follistatin at the start of the 'lag-phase', and the time and duration of the phase, according to the stage reached by day 9

\begin{tabular}{|c|c|c|c|c|c|}
\hline \multirow[b]{2}{*}{ Category } & \multirow[b]{2}{*}{$\begin{array}{l}\text { Number of embryos } \\
\text { developed to } \\
\geq 9-16 \text {-cell }\end{array}$} & \multicolumn{4}{|c|}{ Embryos showing 'lag-phase' } \\
\hline & & Number & $\begin{array}{l}\text { Number of } \\
\text { cells at onset* }\end{array}$ & $\begin{array}{l}\text { Time at onset after } \\
\text { in vitro insemination }\end{array}$ & Duration $^{+}$ \\
\hline \multicolumn{6}{|l|}{ Stage reached by day 9} \\
\hline 9-16-cell & 46 & 46 & $6.3 \pm 0.2^{\mathrm{a}}$ & $51 \mathrm{~h} 03 \pm 1 \mathrm{~h} 08^{\mathrm{a}}$ & $48 \mathrm{~h} 17 \pm 1 \mathrm{~h} 49^{\mathrm{a}}$ \\
\hline Morula & 46 & 42 & $7.0 \pm 0.2^{b}$ & $49 \mathrm{~h} 09 \pm 0 \mathrm{~h} 45^{\mathrm{ac}}$ & $41 \mathrm{~h} 23 \pm 1 \mathrm{~h} 10^{\mathrm{b}}$ \\
\hline Blastocyst & 74 & 71 & $7.1 \pm 0.1^{b}$ & $47 \mathrm{~h} 54 \pm 0 \mathrm{~h} 28^{\mathrm{c}}$ & $41 \mathrm{~h} 03 \pm 0$ h $50^{\mathrm{b}}$ \\
\hline Hatched blastocyst & 23 & 21 & $7.5 \pm 0.2^{\mathrm{b}}$ & $47 \mathrm{~h} 49 \pm 1$ h $03^{c}$ & $37 \mathrm{~h} 27 \pm 1 \mathrm{~h} 27^{\mathrm{b}}$ \\
\hline \multicolumn{6}{|l|}{ Medium } \\
\hline Control & 63 & 60 & $6.7 \pm 0.2^{\mathrm{a}}$ & 47 h $55 \pm 0$ h 39 & $41 \mathrm{~h} 57 \pm 1 \mathrm{~h} 03^{\mathrm{bc}}$ \\
\hline Activin A & 68 & 62 & $7.3 \pm 0.1^{\mathrm{c}}$ & 49 h $26 \pm 0$ h 44 & $40 \mathrm{~h} 33 \pm 0 \mathrm{~h} 52^{\mathrm{b}}$ \\
\hline Follistatin & 58 & 58 & $6.9 \pm 0.1^{\mathrm{a}}$ & 49 h $37 \pm 0$ h 45 & $45 \mathrm{~h} 19 \pm 1 \mathrm{~h} 35^{\mathrm{c}}$ \\
\hline
\end{tabular}

Data are pooled from four replicates.

*Values are means \pm SEM.

${ }^{+}$Mean \pm SEM values expressed in $h$ and $\mathrm{min}$.

abc Values in the same column of the category (stage reached by day 9, or medium) with different superscripts are significantly different (ab $P<0.001$; $P$ c $<0.01$;

ac $P<0.05)$. 


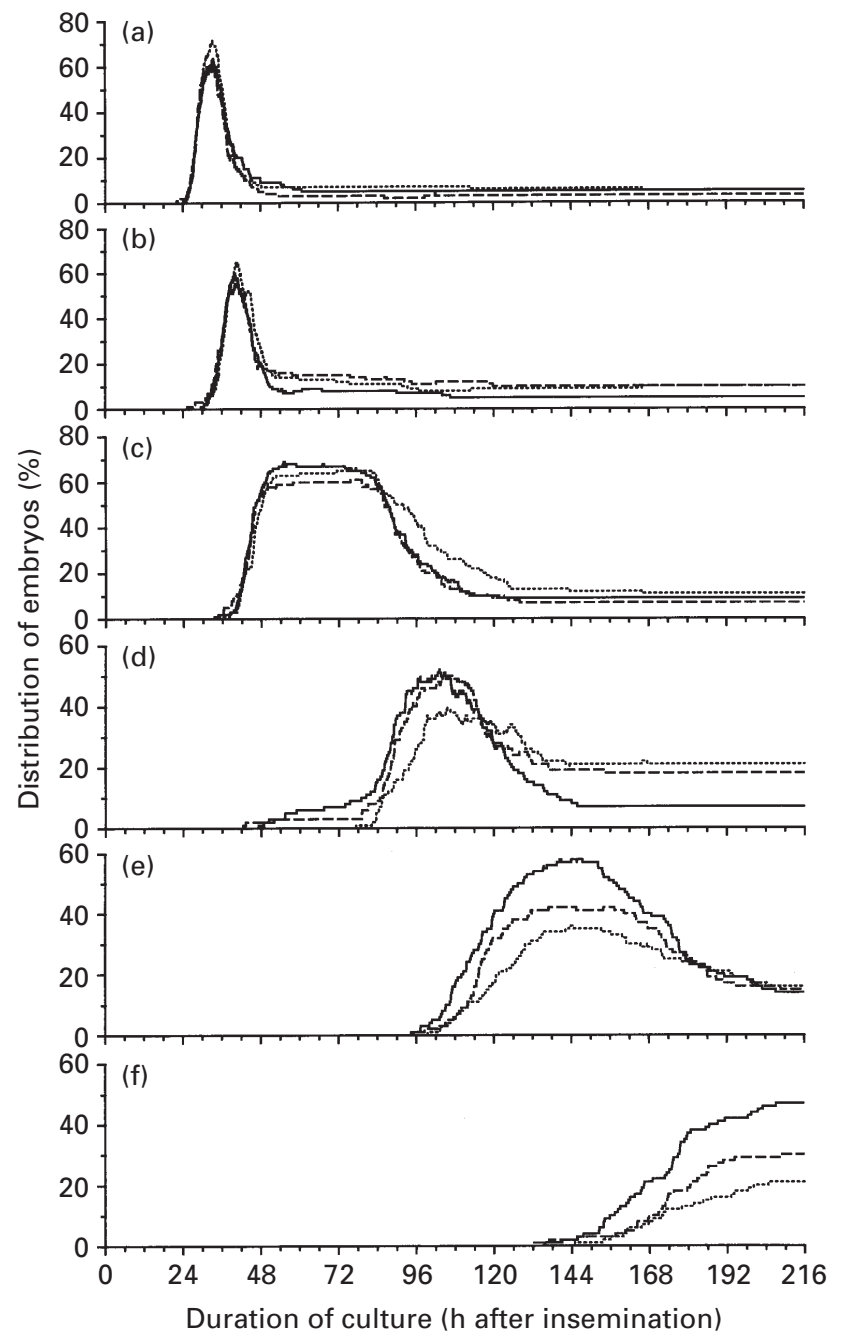

Fig. 1. Distribution (\%) of bovine embryos on development in vitro of presumptive zygotes cultured in modified synthetic oviduct fluid (- - ), modified synthetic oviduct fluid supplemented with activin A (-) and follistatin (...). Proportion of (a) two-cell embryos, (b) three- to four-cell embryos, (c) five- to eight-cell embryos, (d) 9-16cell embryos, (e) morulae and (f) blastocyst-hatched blastocysts during culture are shown. Data are pooled from four replicates in each treatment $(n=100)$.

treatments (Table 3). Activin A significantly increased the proportion of morulae and blastocysts (percentages of presumptive zygotes) at the time of peak emergence compared with follistatin $(P<0.05)$.

\section{Duration of the cycles}

The mean duration of the first four cell cycles in embryos that developed further than the 9-16-cell stage by day 9 is shown (Fig. 2). There were no significant differences in the first and second cell cycles, which ranged from $28 \mathrm{~h} 48 \mathrm{~min}$ to $29 \mathrm{~h} 37 \mathrm{~min}$ and from $7 \mathrm{~h} 21 \mathrm{~min}$ to $7 \mathrm{~h} 52 \mathrm{~min}$, respectively,

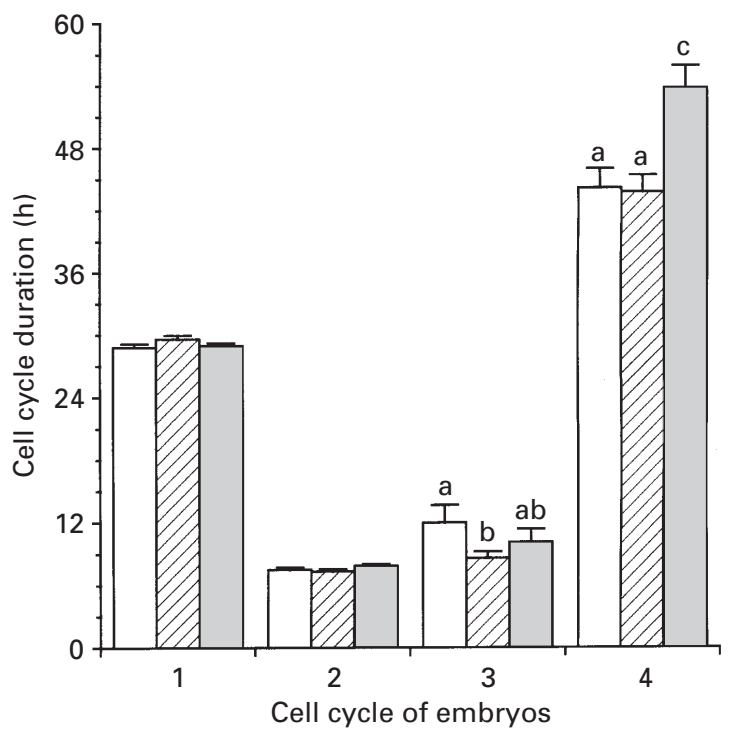

Fig. 2. Duration of cell cycle in bovine embryos cultured in modified synthetic oviduct fluid ( $\square, n=63)$, modified synthetic oviduct fluid supplemented with activin A (还, $n=68$ ) and follistatin $(\square, n=58)$. The durations of the first, second, third and fourth cell cycles of embryos that developed beyond the 9-16-cell stage during culture are shown. Data are presented as mean \pm SEM values. Different letters above the bars within the same cell cycle indicate significant differences $\left({ }^{\mathrm{a}}\right.$ versus $^{\mathrm{b}}: P<0.05{ }^{\mathrm{a}}$ versus $\left.{ }^{\mathrm{c}}: P<0.001\right)$.

between culture treatments. The duration of the third cell cycle $(8 \mathrm{~h} 36 \mathrm{~min})$ was significantly shorter in the ACT culture compared with the control $(12 \mathrm{~h} 00 \mathrm{~min})(P<0.05)$, but the duration was not significantly different in the FS culture (10 h $07 \mathrm{~min})$. The duration of the fourth cell cycle in the FS culture (53 h $50 \mathrm{~min})$ was significantly $(P<0.001)$ longer than that it was in control (44 h $13 \mathrm{~min})$ and ACT cultures (43 h $48 \mathrm{~min}$ ).

\section{Developmental arrest at early cleavage stage}

The characteristics of the developmental arrest ('lagphase') are summarized (Table 4). In all culture treatments, the lag-phase during the four- to eight-cell stage was observed in $95 \%$ of embryos reaching further than 9-16-cell stage by day 9 . The mean number of cells in embryos at the onset of the lag-phase was significantly $(P<0.001)$ lower in embryos that ceased to develop at the 9-16-cell stage than in those that developed to the morula, blastocyst or hatched blastocyst stages on day 9. The time of onset of the lagphase in embryos that ceased to develop at the 9-16-cell stage was significantly $(P<0.05)$ later than it was in embryos that developed to blastocysts and hatched blastocysts. In addition, the mean duration of the lag-phase in embryos that ceased to develop at the 9-16-cell stage was significantly $(P<$ 0.001) longer than it was in embryos that developed to the morula, blastocyst and hatched blastocyst stages. Moreover, there was a significant rank correlation between the stage 
that embryos reached by day 9 and either the number of cells of embryos at the onset of the lag-phase $(r=-0.31 ; P<0.001)$, the time of onset of the lag-phase $(r=-0.20 ; P<0.01)$ or the duration of the lag-phase $(r=-0.31 ; P<0.001)$. There was no significant difference in the time of onset of the lag-phase among the three treatment conditions. However, culture in ACT significantly $(P<0.05)$ increased the number of cells in embryos at the onset of the lag-phase compared with control and FS cultures. Furthermore, ACT culture significantly $(P<0.01)$ shortened the mean duration of the lag-phase compared with FS culture.

\section{Discussion}

The present study used cinematographic analysis to show that activin A and follistatin influenced the developmental kinetics of cultured bovine embryos matured and fertilized in vitro. Grisart et al. (1994) reported that the developmental rate of bovine embryos produced by in vitro maturation and fertilization and cultured under the conditions necessary for cinematography was similar to that of control embryos placed in serum-free oviduct-conditioned medium. In the present study, the developmental rates of embryos in the time-lapse group were similar to those in the incubator group. Activin A increased and follistatin decreased the developmental rate to morulae and blastocysts in the present study, confirming the findings of Yoshioka et al. (1998a).

The timing of early cleavage in bovine embryos developed in vivo or in vitro has been investigated by several groups (Prather and First, 1988; Grisart et al., 1994; Van Langendonckt et al., 1997). It is generally recognized that, in bovine embryos produced in vitro, development is slower than in those developed in vivo, especially after the eight-cell stage (Barnes and Eyestone, 1990). The time of cleavage at each developmental stage in the present study could not be compared unconditionally with those reported elsewhere since these parameters are influenced by culture conditions. However, in general, the time of cleavages in the present study followed the trend reported previously for in vitro cultures of bovine embryos produced by in vitro maturation and fertilization (Van Soom et al., 1992; Grisart et al., 1994; Van Langendonckt et al., 1997; Holm et al., 1998). In the present study, addition of follistatin to the chemically defined medium, mSOF, delayed the time of the first appearance of 9-16-cell embryos.

The durations of the first, second, third and fourth cell cycles of bovine embryos developed in vivo are approximately 32, 13, 14 and $24 \mathrm{~h}$, respectively (First and Barnes, 1989). In contrast, the first, second, third and fourth cell cycles of embryos developed in vitro were reported to be about 34, 14, 11 and 54 h, respectively by Grisart et al. (1994), and 32, 9, 11 and 48 h, respectively, by Holm et al. (1998). These data indicate that the fourth cell cycle is usually prolonged in bovine embryos developed in vitro, resulting in a delay in the timing of development after the 9-16-cell stage, compared with embryos developed in vivo. In the present study, the durations of the first, second and third cell cycles were 30,7 and $8 \mathrm{~h}$, respectively, when ACT culture was used. These periods were slightly shorter than those reported previously for in vitro and in vivo studies. Furthermore, the duration of the fourth cell cycle in ACT culture was around $43 \mathrm{~h}$, which was also slightly shorter than in previous in vitro, but not in vivo, studies.

Accurate measurement of the duration of early cleavages in bovine embryos showed a developmental arrest ('lag-phase') for 41-47 h at the four- to eight-cell stage (Grisart et al., 1994; Van Langendonckt et al., 1997; Holm et al., 1998). In the present study, the lag-phase was observed in $95 \%$ of embryos that developed beyond the 9-16-cell stage. The duration of cell cycles and parameters of the lag-phase, such as the number of cells in embryos at the onset of the phase and the duration of the phase, may reflect the developmental competence and may influence the subsequent development of bovine embryos. Holm et al. (1998) reported that the duration of the first and second cell cycles was prolonged in embryos that ceased developing before the compact morula stage, compared with embryos developed to at least the compact morula stage, and that a similar tendency was also seen in the third and fourth cell cycles. Grisart et al. (1994) showed, using a small sample (13 embryos), that embryos entering the lag-phase at the eight-cell stage developed more morulae and blastocysts (three of four embryos) than did those arrested at earlier stages (two of nine embryos). In the present study, there were fewer cells at the onset of the lag-phase, the time of entry into the lag-phase was later and the duration of the lag-phase was longer in embryos that ceased to develop at the 9-16-cell stage than in embryos that were further developed. In addition, there was a significant correlation between the stage that embryos reached by day 9 and the number of cells in embryos at the onset of the lag-phase, the time of onset of the phase and the duration of the lag-phase. These results indicate that developmental competence is generally higher for embryos with a greater number of cells at the onset of the lag-phase, an earlier time of onset of the lag-phase or a shorter duration of the lag-phase.

The time of the first cleavage after insemination is correlated directly with developmental potential, as assessed by the developmental rates of embryos to the compacted morula, blastocyst and hatched blastocyst stages (Van Soom et al., 1992, 1997; Holm et al., 1998). In the present study, the development of embryos cleaving earliest (before $30 \mathrm{~h}$ after insemination) was superior to that of those cleaving later (74/161, $46 \%$ versus $24 / 93,26 \%$ ) but no difference was observed among treatments (data not shown). In contrast, the addition of activin A to mSOF increased the number of cells at the onset of the lag-phase, although it did not affect the time of entry to the lag-phase. Moreover, activin A shortened the duration of the lag-phase compared with follistatin. Since activin A may be produced by the bovine embryo itself and follistatin neutralizes the action of activin A (Yoshioka et al., 1998a; 1998b), the action of activin A may be to shorten the duration of the lag-phase as well as to increase the number of cells at the onset of the lag-phase. Thus, activin A may enhance the development of bovine embryos to the blastocyst stage by improving the developmental kinetics, especially at the stage of entry into the lag-phase, and shortening the duration of the phase. This argument is supported by the finding that activin A enhances the development of embryos when they are exposed to activin A before the 9-16-cell stage (Yoshioka et al., 1998a). 
The developmental kinetics of bovine embryos are affected by culture conditions. Suboptimal conditions during the third and fourth cell cycles may lead to '8-16-cell block' which is a complete developmental arrest at the 8-16-cell stage (Thibault, 1966; Camous et al., 1984; Heyman et al., 1987; Eyestone et al., 1987; Edwards et al., 1997). In normal development, the activation of zygotic transcription, which occurs after the transition from maternal to zygotic control of development, needs to occur at a particular time. In bovine embryos, the major zygotic gene activation appears during developmental arrest in the fourth cell cycle (Frei et al., 1989; Barnes and First, 1991). Considered together, these findings indicate that the lag-phase and major zygotic gene activation are linked because developmental arrest is caused by prolongation of $G_{2}$ phase (Barnes and Eyestone, 1990) in which chromatin remodelling occurs with major zygotic gene activation (Thompson et al., 1995; De Sousa et al., 1998). Thus, the parameters of the lag-phase may reflect the quantitative or qualitative effects of major zygotic gene activation. It is possible that activin A enhances the development in vitro of bovine embryos by improving the quantitative or qualitative effects of major zygotic gene activation. The present results showed that the greater the number of cells in embryos at the onset of the lag-phase, the further the embryos had developed by day 9. Thus, subsequent development may be enhanced when major zygotic gene activation occurs at about the eight-cell stage.

The results of studies using bovine embryos transfected with reporter genes at the one-cell stage indicate that the timing of major zygotic gene activation may be controlled temporally rather than by developmental stage (Gagne et al., 1995; Kubisch et al., 1997). In contrast to the stage at onset of the lag-phase and the duration of the phase, the timing of the initiation of the lag-phase was not affected by activin A or follistatin. The initiation of the lag-phase may also be controlled temporally, for example by time after fertilization.

In conclusion, activin A shortened the duration of the third or fourth cell cycle of bovine embryos. This shortening resulted from deferring the stage of developmental arrest (lag-phase) and shortening the arrest period. The present results showed a clear relationship between the parameters of the lag-phase and subsequent development. Activin A may enhance the development in vitro of bovine embryos by improving the developmental kinetics during early cleavage, especially at the stage of the onset of the lag-phase, and by shortening the duration of the phase.

This work was supported by a grant from Ministry of Agriculture, Forestry and Fisheries of Japan. The authors thank the National Hormone and Pituitary Program, NIDDK, NICHD, and USDA for providing recombinant human follistatin.

\section{References}

Barnes FL and Eyestone WH (1990) Early cleavage and the maternal zygotic transition in bovine embryos Theriogenology 33 141-152

Barnes FL and First NL (1991) Embryonic transcription in in vitro cultured bovine embryos Molecular Reproduction and Development 29 117-123

Bavister BD (1988) A minichamber device for maintaining a constant carbon dioxide in air atmosphere during prolonged culture of cells on the stage of an inverted microscope In Vitro Cellular and Developmental Biology 24 759-763

Bavister BD, Leibfried ML and Lieberman G (1983) Development of preimplantation embryos of the golden hamster in a defined culture medium Biology of Reproduction 28 235-247

Camous S, Heyman Y, Méziou W and Ménézo Y (1984) Cleavage beyond the block stage and survival after transfer of early bovine embryos cultured with trophoblastic vesicles Journal of Reproduction and Fertility 72 479-485

De Sousa PA, Watson AJ, Schultz GA and Bilodeau-Goeseels S (1998) Oogenetic and zygotic gene expression directing early bovine embryogenesis: a review Molecular Reproduction and Development 51 112-121

Edwards LJ, Batt PA, Gandolfi F and Gardner DK (1997) Modifications made to culture medium by bovine oviduct epithelial cells: changes to carbohydrates stimulate bovine embryo development Molecular Reproduction and Development 47 146-154

Eyestone WH, Vignieri J and First NL (1987) Co-culture of early bovine embryos with oviductal epithelium Theriogenology 27 Abstract 228

First NL and Barnes FL (1989) Development of preimplantation mammalian embryos Progress in Clinical and Biological Research 294 151-170

Frei RE, Schultz GA and Church RB (1989) Qualitative and quantitative changes in protein synthesis occur at the 8-16-cell stage of embryogenesis in the cow Journal of Reproduction and Fertility 86 637-641

Gagne M, Pothier F and Sirard MA (1995) Effect of microinjection time during postfertilization S-phase on bovine embryonic development Molecular Reproduction and Development 41 185-192

Grisart B, Massip A and Dessy F (1994) Cinematographic analysis of bovine embryo development in serum-free oviduct-conditioned medium Journal of Reproduction and Fertility $101257-264$

Heyman Y, Ménézo Y, Chesne P, Camous S and Garnier V (1987) In vitro cleavage of bovine and ovine early embryos: improved development using coculture with trophoblastic vesicles Theriogenology 27 59-68

Holm P, Shukri NN, Vajta G, Booth P, Bendixen C and Callesen H (1998) Developmental kinetics of the first cell cycles of bovine in vitro produced embryos in relation to their in vitro viability and sex Theriogenology 50 1285-1299

Kubisch HM, Larson MA, Eichen PA, Wilson JM and Roberts RM (1997) Adenovirus-mediated gene transfer by perivitelline microinjection of mouse, rat and cow embryos Biology of Reproduction 56 119-124

Massip A and Mulnard J (1980) Time-lapse cinematographic and morphometric analysis Journal of Reproduction and Fertility 58 475-478

Mulnard JG (1967) Analyse microcinématographique du developpement de l'oeuf de souris du stade II au stade blastocyste Archives de Biologie 78 107-138

Prather RS and First NL (1988) A review of early mouse embryogenesis and its applications to domestic species Journal of Animal Science 66 2626-2635

Takahashi Y and First NL (1992) In vitro development of bovine one-cell embryos: influence of glucose, lactate, pyruvate, amino acids and vitamins Theriogenology 37 963-978

Thibault C (1966) La culture in vitro de l'oeuf vache Annales de Biologie Animale, Biochimie, Biophysique 6 159-164

Thompson EM, Legouy E, Christians E and Renard JP (1995) Progressive maturation of chromatin structure regulates $h s p 70.1$ gene expression in the preimplantation mouse embryo Development 121 3425-3437

Van Langendonckt A, Donnay I, Schuurbiers N, Auquier P, Carolan C, Massip A and Dessy F (1997) Effects of supplementation with fetal calf serum on development of bovine embryos in synthetic oviduct fluid medium Journal of Reproduction and Fertility 109 87-93

Van Soom A, Van Vlaenderen I, Mahmoudzadeh AR, Deluyker H and de Kruif A (1992) Compaction rate of in vitro fertilized bovine embryos related to the interval from insemination to first cleavage Theriogenology 38 905-919

Van Soom A, Ysebaert MT and de Kruif A (1997) Relationship between timing of development, morula morphology, and cell allocation to inner cell mass and trophectoderm in in vitro-produced bovine embryos Molecular Reproduction and Development 47 47-56

Yoshioka K and Kamomae H (1996) Recombinant human activin A stimulates development of bovine one-cell embryos matured and fertilized in vitro Molecular Reproduction and Development 45 151-156

Yoshioka K, Suzuki C and Iwamura S (1998a) Activin A and follistatin regulate developmental competence of in vitro-produced bovine embryos Biology of Reproduction 59 1017-1022

Yoshioka K, Takata M, Taniguchi T, Yamanaka H and Sekikawa K (1998b) Differential expression of activin subunits, activin receptors and follistatin genes in bovine oocytes and preimplantation embryos Reproduction, Fertility and Development $10293-298$ 